\title{
Impact of Gun-hunting on Diurnal Primates in Continental Equatorial Guinea
}

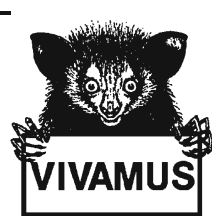

\author{
Noëlle F. Kümpel • E. J. Milner-Gulland • \\ Guy Cowlishaw • J. Marcus Rowcliffe
}

Published online: 9 July 2008

(C) Springer Science + Business Media, LLC 2008

Due to a publication error, a corrupted version of Fig. 1 was published in the article. We regret the error and publish a corrected version of the figure here.

The online version of the original article can be found at http://dx.doi.org/10.1007/s10764-008-9254-9.

\footnotetext{
N. F. Kümpel $(\bowtie)$

Zoological Society of London, Regent's Park, London NW1 4RY, UK

e-mail: noelle.kumpel@zsl.org

\section{N. F. Kümpel}

Department of Anthropology, University College London, 14 Taviton Street, London WC1H 0BW, UK

\section{N. F. Kümpel • E. J. Milner-Gulland}

Division of Biology, Imperial College London, Silwood Park Campus, Ascot, Berkshire SL5 7PY, UK 


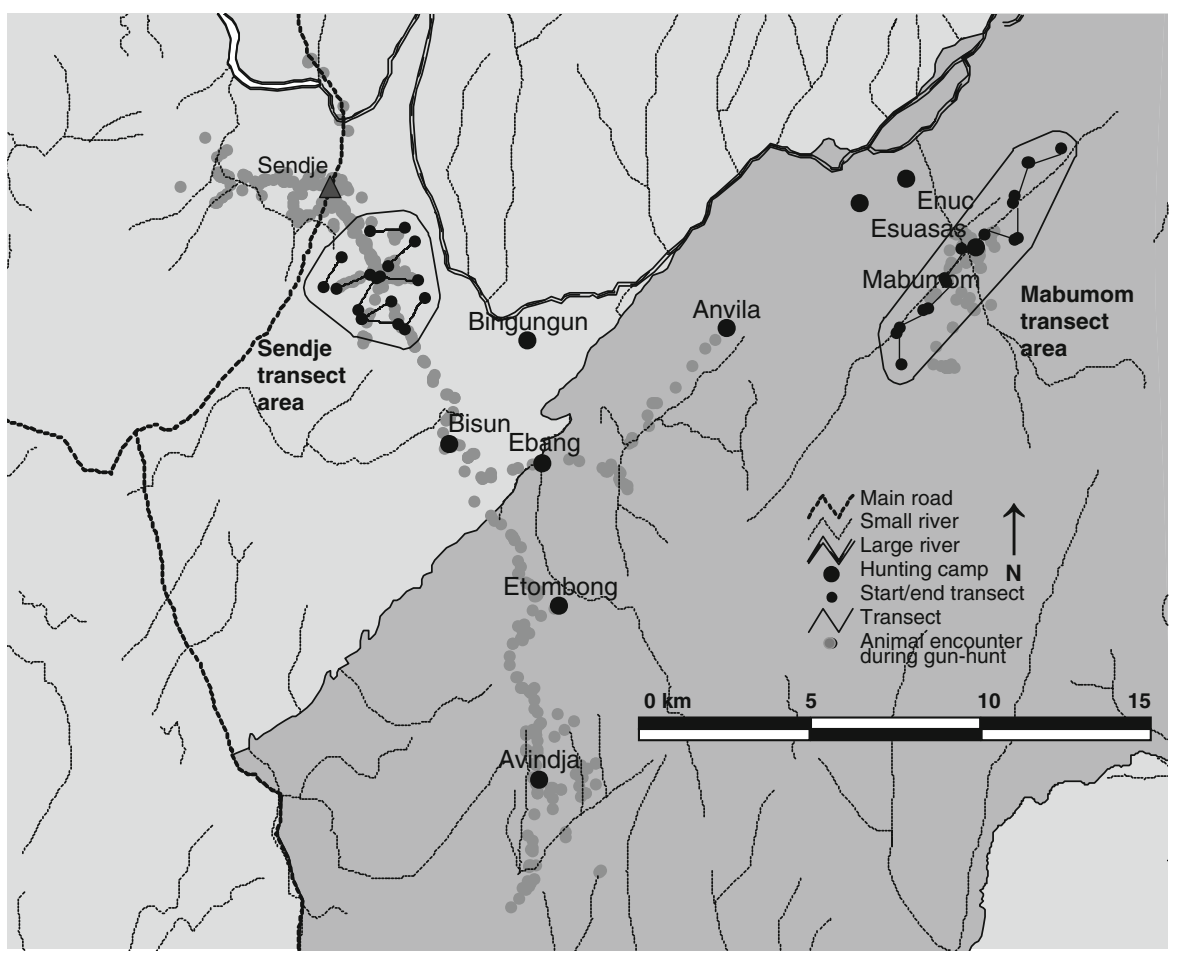

Fig. 1 Study area, showing hunter camps, hunter follows, and location of transects. Sendje is demarcated by a black triangle, hunter camps by large black dots, subject encounters during hunter follows by small gray dots, and transects by black lines. Transect zones (calculated as the area of a minimum convex polygon encircling the group of transects in each site, including a 500-m buffer to account for typical Colobus satanus home range size of $\geq 30$ ha: Gautier-Hion et al. 1999) are circled. The darker gray area is Monte Alén National Park. 